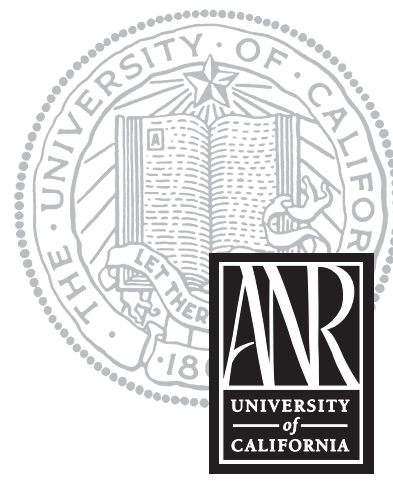

UNIVERSITY OF CALIFORNIA

Division of Agriculture and Natural Resources

http://anrcatalog.ucdavis.edu

\title{
PUBLICATION 8025
}

\section{Frequently Asked Questions about Pitch Canker}

ANDREW J. STORER, Assistant Research Entomologist, Division of Insect Biology, Department of Environmental Science, Policy, and Management, UC Berkeley;

DAVID L. WOOD, Professor, Division of Insect Biology, Department of Environmental Science, Policy, and Management, UC Berkeley; and THOMAS R. GORDON, Professor of Plant Pathology, Department of Plant Pathology, UC Davis.

\section{Questions}

1. What is pitch canker?

2. What does pitch canker look like?

3. Where is pitch canker found?

4. What trees in California are affected by pitch canker?

5. Are all susceptible tree species affected to the same extent?

6. What causes pitch canker?

7. How does pitch canker spread?

8. Are there Monterey Pine trees that do not get pitch canker?

9. Is there a cure for pitch canker?
10. Will pruning-out infected branches slow the decline of the tree?

11. Can I prevent pitch canker from getting into my trees?

12. What should I do if I think a tree has pitch canker?

13. How far will pitch canker spread?

14. What can I do to help?

15. Where can I get more information about pitch canker?

\section{Q. 1. What Is Pitch Canker?}

A. Pitch Canker is a disease that causes die-back of individual pine branches (Figure 1), leading to a general decline in tree health, and, in some cases, premature death. This disease mainly affects pine trees in central coastal areas of California.

\section{Q. 2. What Does Pitch Canker Look Like?}

A. The earliest symptoms of pitch canker usually are dead branch tips in the upper part of the tree canopy. Needles on the ends of these branches are either wilted (Figure 2), red, brown, or absent, and resin exudation is associated with the point of infection on the branch (Figure 3). A more advanced symptom of the disease is the appearance of resinous cankers with heavy exudation of pitch on the main stem and larger branches of the tree (Figure 4). After these stem cankers appear, the top of the weakened tree may be killed by bark beetles and the entire tree may die.

\section{Q. 3. Where Is Pitch Canker Found?}

A. In the United States before 1986, pitch canker was only known to occur in the southeastern states. The disease was first recognized in California in 1986. It has also been found in Mexico, Japan, Spain, and South Africa. In California, pitch canker is at this time limited mostly to coastal areas from San Diego to Mendocino Counties. To date there are no confirmed occurrences of pitch canker in the Sierra Nevada or other locations east of the Central Valley or farther north than Mendocino County. 


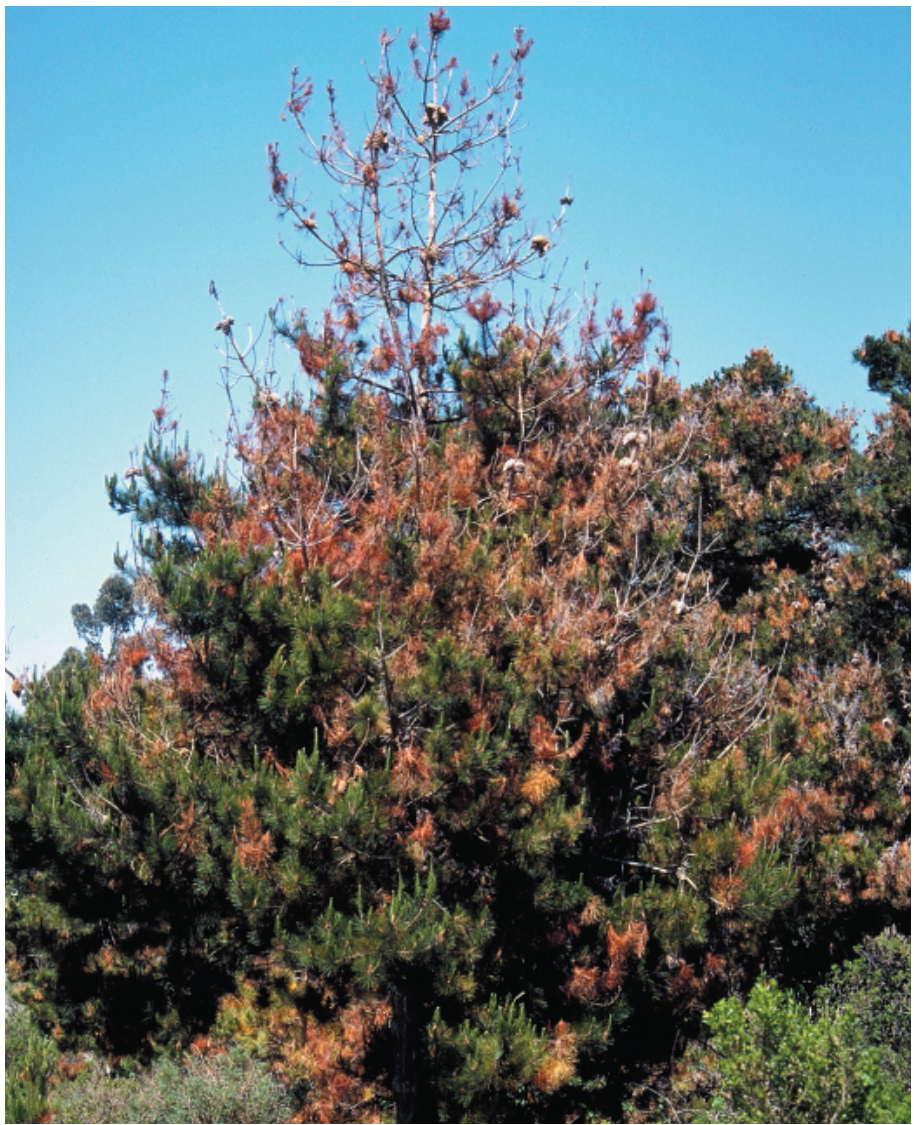

Figure 1. Multiple branch tip infections and dead tree top resulting from pitch canker in Monterey pine.

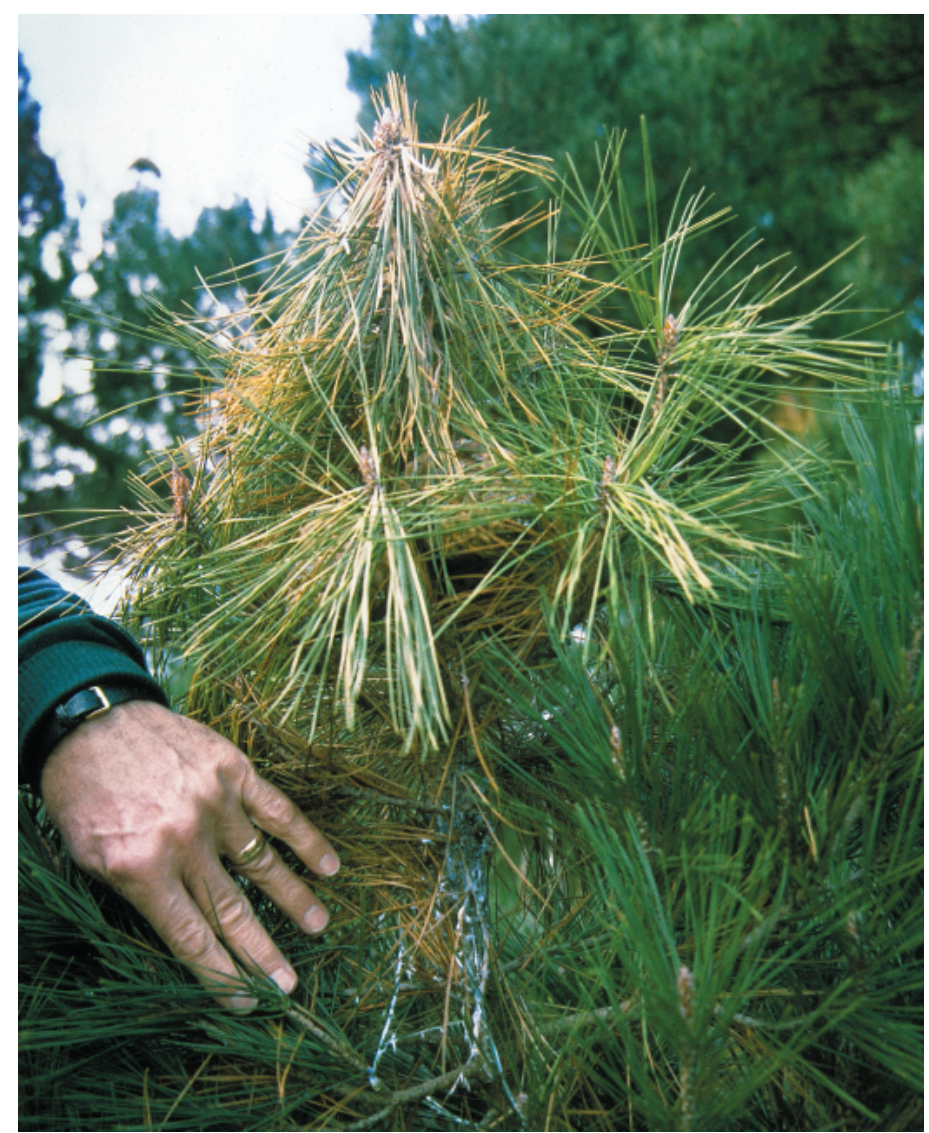

Figure 3. Resin exudation from infected Monterey pine branch tip. Needles distal to the point of infection wilt and die.

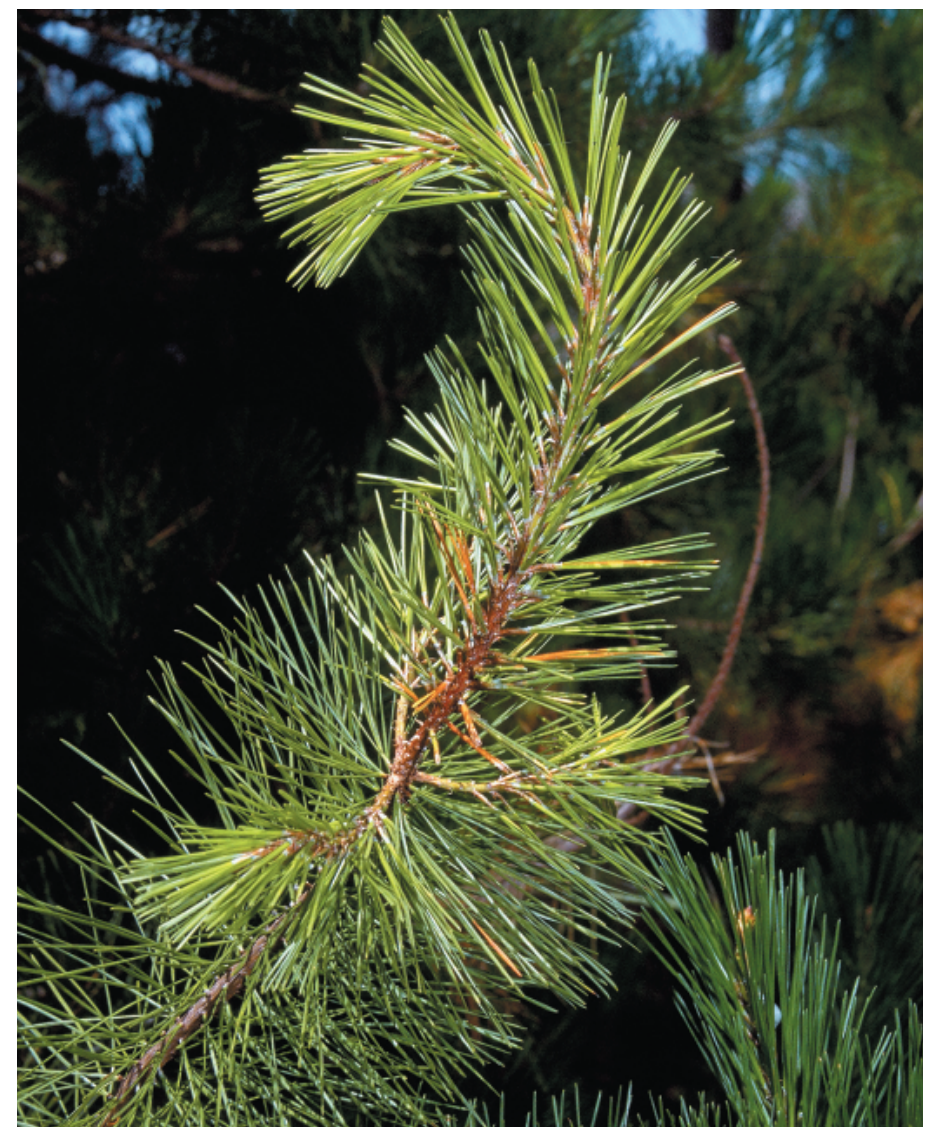

Figure 2. Infected Monterey pine shoot. Discolored area of shoot is the lesion resulting from infection by the pathogen. Note the wilting of the tip of this shoot.

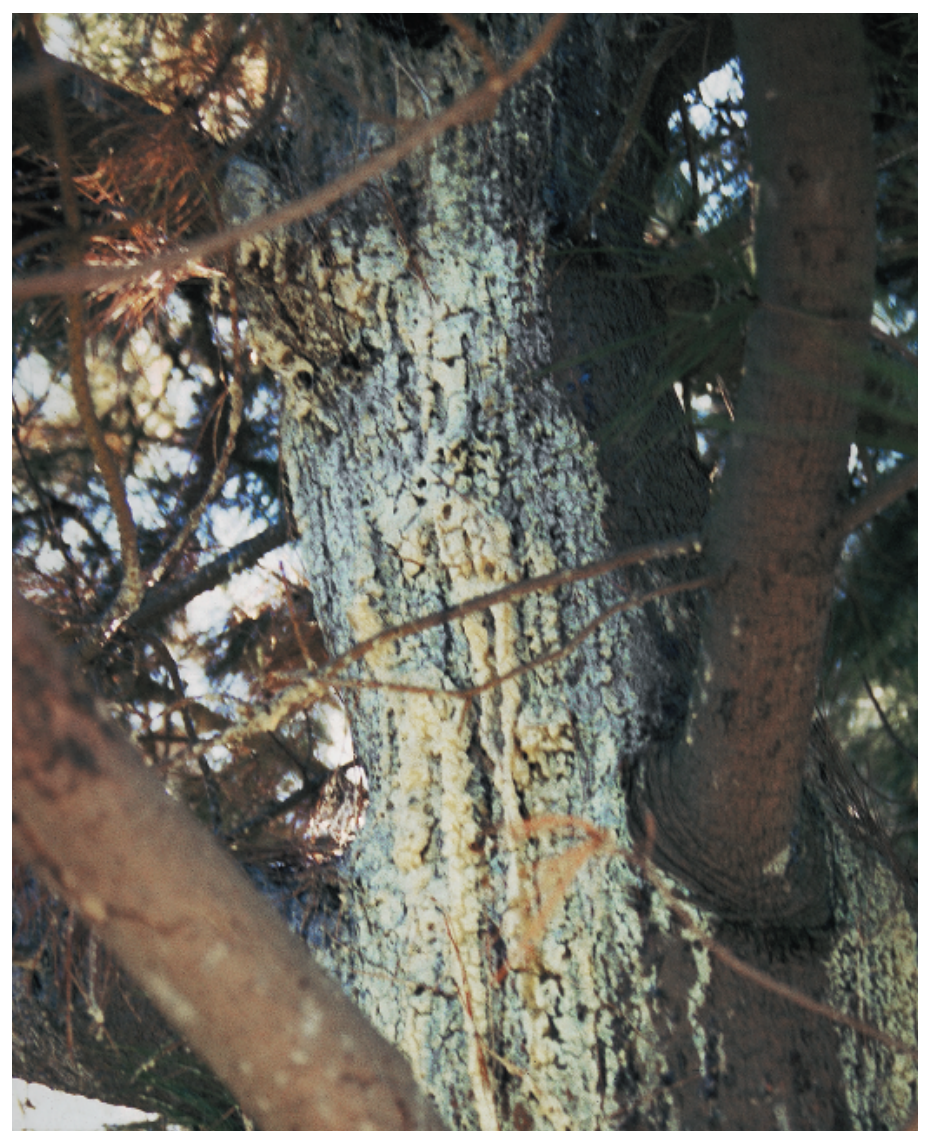

Figure 4. Cankers on the main stem result in copious exudation of resin. 


\section{Q. 4. What Trees in California Are Affected by Pitch Canker?}

A. Pitch canker affects many native pines in California, including Monterey pine, Bishop pine, knobcone pine, gray (=foothill) pine, coulter pine, Torrey pine, ponderosa pine, and shore pine. Douglas-fir, another native California conifer, is also susceptible, although less so than most pines. For Monterey, Bishop, and knobcone pines, infected trees have been observed in native forests. Pitch canker only affects pines (and occasionally Douglas-fir), and should not be confused with other canker diseases such as cypress canker.

\section{Q. 5. Are All Susceptible Tree Species Affected to the Same Extent?}

A. No. Of the native pines, Monterey and Bishop pines are very susceptible and are the most widely affected. Knobcone pine and shore pine are also severely affected in some areas. Other native species are known to be susceptible based on greenhouse tests, but these species are not common in the areas where pitch canker is found and as a consequence infected trees are rarely seen. Among nonnative pine species commonly found in landscape settings in California, Canary Island and Italian stone pines are relatively resistant to pitch canker. Aleppo pine is intermediate in susceptibility.

\section{Q. 6. What Causes Pitch Canker?}

A. Pitch canker is caused by a fungus called Fusarium circinatum. Older names for this fungus include Fusarium subglutinans f. sp. pini and Fusarium moniliforme var. subglutinans. Many other Fusarium species are commonly found in soil; some cause wilt diseases, but many are not pathogenic to plants.

\section{Q. 7. How Does Pitch Canker Spread?}

A. The pathogen produces airborne spores that can be spread by wind and carried by native insects. Insects known to carry the pathogen include bark beetles and twig beetles (which, respectively, feed under the bark of large- and small-diameter tree material) and cone beetles (which attack cones on the host tree). Many of these insects are known to transmit the pitch canker fungus to healthy trees and they are considered to be the primary means by which new infections are established. Although flying beetles can spread the disease to new areas, long-distance spread is more likely to result when people transport insect- or pathogen-infested logs, nursery stock, seeds, or soil. The pathogen is known to be able to survive for long periods in these media.

\section{Q. 8. Are There Any Monterey Pine Trees That Do Not Get Pitch Canker?}

A. Yes. Some Monterey pine trees are resistant to pitch canker. In addition, some trees in long-term survey areas have exhibited only a very limited amount of damage from the fungus. These trees are not expected to die from the disease unless new strains of the fungus capable of overcoming the trees' natural resistance are introduced into the state.

\section{Q. 9. Is There a Cure for Pitch Canker?}

A. There are no practical, direct methods to control pitch canker. However, actions can be taken to slow the spread of the pathogen, including techniques that reduce the number of insects emerging from diseased plant material. These methods include debarking recently killed trees and branches and 
timely chipping and removal of diseased or insect-infested tree material from nearby susceptible trees.

\section{Q. 10. Will Pruning-Out Infected Branches Slow the Decline of the Tree?}

A. In most areas where pitch canker occurs, infected branch tips are so numerous that removing them all is not a practical option. Even where removal is possible, repeated pruning will almost certainly be necessary as new infections are likely to occur. Where the incidence of the disease is isolated, the timely removal of diseased branch tips may effectively slow the spread of the disease. The benefits of this practice, however, have not been demonstrated in full-scale field studies.

\section{Q. 11. Can I Prevent Pitch Canker from Getting into My Trees?}

A. No proven method is currently available for preventing pitch canker from infecting susceptible trees in areas where the fungus is established.

\section{Q. 12. What Should I Do if I Think a Tree Has Pitch Canker?}

A. If other trees in the area have pitch canker, there is little that can be done for an individual tree. Tree removal should only be considered if a tree becomes hazardous or unacceptably unsightly. A confirmed diagnosis of the disease requires isolation of the fungus. Details on this procedure are available from your county agriculture commissioner's office and your local UC Cooperative Extension county office.

\section{Q. 13. How Far Will Pitch Canker Spread?}

A. Given the geographic range of susceptible host tree species, the potential for spread is great and includes the northern coast of California and the Sierra Nevada. Work is underway to determine whether climatic conditions, differences in host susceptibility, or insect vectoring potential will limit spread of the disease.

\section{Q. 14. What Can I Do to Help?}

A. The potential for the spread of pitch canker into the forests of the Sierra Nevada is a major concern. To help reduce the risk that this will occur, no Monterey pine or other pine material should be transported from west of Interstate 5 to east of Interstate 5. Any firewood, cones, logs, or chipped pine material should be used in the local area where it originated. These types of material may carry the fungus, its insect vectors, or both, and they will increase the risk that the disease will spread if they are transported outside of the local area.

\section{Q. 15. Where Can I Get More Information about Pitch Canker?}

A. Information is available from various sources including printed documents and information on the Internet. Documents and links relating to pitch canker can be found at this URL: 


\section{ADDITIONAL READING}

Gordon, T. R., D. Okamoto, A. J. Storer, and D. L. Wood. 1998. Susceptibility of five landscape pines to pitch canker disease, caused by Fusarium subglutinans f. sp. pini. Hortscience 33: 868-871.

Gordon, T. R., K. R. Wikler, A. J. Storer, and D. L. Wood. 1997. Pitch canker and its potential impacts on Monterey pine forests in California. Fremontia 25(2): 5-9.

Storer, A. J., P. L. Dallara, D. L. Wood, and T. R. Gordon. 1995. Pitch canker disease of pines. Calif. Dept. Forestry and Fire Protection, California Forestry Note. \#220, 18 pp. http://frap.cdf.ca.gov/pitch_canker/pitchcan.html

Storer, A. J., T. R. Gordon, D. L. Wood, and P. Bonello. 1997. Current and future impacts of pitch canker disease of pines. Journal of Forestry 10(12): 21-26.

\section{FOR MORE INFORMATION}

You'll find detailed information on many aspects of disease prevention in the landscape and garden in these and other publications, slide sets, and videos from UC ANR:

Pests of Landscape Trees \& Shrubs: An Integrated Pest Management Guide, Publication 3359

CD-ROM: UC Guide to Solving Garden and Landscape Problems, Publication 3400

UC IPM Pest Management Guidelines, Publication 3339

To order these products, visit our online catalog at http://anrcatalog.ucdavis.edu. You can also place orders by mail, phone, or fax, or request a printed catalog of publications, slide sets, and videos from

University of California

Agriculture and Natural Resources

Communication Services

6701 San Pablo Avenue, 2nd Floor

Oakland, California 94608-1239

Telephone: 1-800-994-8849 or (510) 642-2431, FAX: (510) 643-5470

e-mail inquiries: danrcs@ucdavis.edu

An electronic version of this publication is available on the DANR Communication Services website at http://anrcatalog.ucdavis.edu.

\section{Publication 8025}

(C) 2001 by the Regents of the University of California,

Division of Agriculture and Natural Resources. All rights reserved.

The University of California prohibits discrimination against or harassment of any person employed by or seeking employment with the University on the basis of race, color, national origin, religion, sex, physical or mental disability, medical condition (cancer-related or genetic characteristics), ancestry, marital status, age, sexual orientation, citizenship, or status as a covered veteran (special disabled veteran, Vietnam-era veteran or any other veteran who served on active duty during a war or in a campaign or expedition for which a campaign badge has been authorized). University Policy is intended to be consistent with the provisions of applicable State and Federal laws. Inquiries regarding the University's nondiscrimination policies may be directed to the Affirmative Action/Staff Personnel Services Director, University of California, Agriculture and Natural Resources, 1111 Franklin, 6th Floor, Oakland, CA 94607-5200 (510) 987-0096. For information about obtaining this publication, call 1-800-994-8849.

pr-4/01-WJC/CR

This publication has been anonymously peer reviewed for technical accuracy by University of California scientists and other qualified professionals. This review process was managed by the ANR Associate Editor for Natural Resources. 